\title{
33 Declaring a climate emergency
}

\author{
Alan Reid
}

\section{How to use this policy}

In October 2018, the Intergovernmental Panel on Climate Change (IPCC) published a landmark Special Report on Climate Change. The report warns that 2030 is humanity's deadline to limit catastrophic climate change around the planet. During the 2020s, teachers and learners are expected to play their part in responding to this global declaration of a climate emergency, with schools being tasked with accelerating the adoption of "wide-scale behaviour changes consistent with adapting to and limiting global warming" (IPCC, 2018, §D5.6).

Declaring a climate emergency is a concrete indication of a school's willingness to commit to telling the truth about the reality of climate breakdown. An associated policy should be used to bring the school community together, drawing on the energy, ideas, and capacities of the school community, even though the policy is likely to be demanding and far-reaching.

A school's policy on the climate emergency can be easily informed by international, publicly available scientific data, and political and civic initiatives around climate breakdown. School policy creators are encouraged to edit, delete, and build upon suggestions below to create a policy that best represents their school's capacity and commitment to respond to the climate emergency and to use the recommended sources and readings to develop action plans and processes that align with their policy.

[To adapt and use this policy, delete or modify the text as indicated]

\section{[INSERT name of school] Climate emergency policy}

\section{Rationale}

Declaring a climate emergency is a concrete step for the school and its community to contribute to ongoing local, national, and international work undertaken since 1992, addressing the United Nations Framework Convention on Climate Change (UNFCCC, 1992). 
Progress is reviewed each year at the Conference of the Parties (COP) Climate Change meetings. However, the lack of significant political leadership and coordinated international progress aligned to the Paris Accord (UNESCO, 2015; UNFCC, 2015) coupled with frustration at societal inaction (Drews \& van den Bergh, 2016; Drummond et al., 2018; Gifford, 2011; Hamilton \& Kasser, 2009) has led to civil society level responses such as school strikes for climate (e.g. Thunberg, 2019; UNICEF, 2012) and wider calls for action in communities, particularly when national political leadership is found wanting (Reid, 2019; UNESCO, 2019).

For schools and other educational institutions, refocusing education policy and practice to address this shortfall is both a popular and effective response (Dillon, 2019; Feinstein \& Mach, 2020; Hestres, 2018; Monroe et al., 2019; Ogunbode et al., 2020). Their calls to action reiterate the charge that K-12, further/vocational, and higher education systems, government, media, civil society, business, and public sectors have direct responsibilities for mitigating climate disruption through climate-related education, training, public awareness, communication, and behaviour change (Armstrong et al., 2018; IPCC, 2018; Kagawa \& Selby, 2010; Ma et al., 2019; NRC, 2010; UNESCO \& UNFCCC, 2016; Whitmarsh et al., 2010).

Declaring a climate emergency contributes to the UN's Sustainable Development Goal [SDG] 13, "Take urgent action to combat climate change and its impacts" (UN, 2020). If it is to be achieved by 2030, it requires policy that commits schools to help address SDG Target 13.3: "Improve education, awareness-raising and human and institutional capacity on climate change mitigation, adaptation, impact reduction and early warning" (UN, 2020).

Those preparing for and declaring a climate emergency policy network with other schools and education leaders and providers addressing these goals and targets can learn from them. Research and evaluation have also helped identify and share good practices and tackle challenges, with the policy drawing on high-quality studies and evidence (for example, Otto et al., 2020; UNESCO, 2016; Wibeck, 2014).

Simple actions aligned with this policy include following \#schoolCED on social media and completing Climate Change Certification as a Lead Teacher for Climate Change Education, via https://unccelearn.org/educcate/.

\section{Purpose}

A meaningful climate emergency declaration is a serious policy commitment. It entails undertaking responsible and responsive climate action and measurable systemic change in the school and its community. The purpose of committing to these changes is to contribute to wider and deeper initiatives designed to ensure a sustainable future for all, be that within the current school community, the next generation, or for those who have left the school. 


\section{Scope}

This policy applies to present students, teachers, staff, school leaders, and parents of [INSERT name of school]. A whole-of-institution approach to the climate emergency is overseen by all members of the school community and is headed by a member of the senior leadership team in collaboration with key stakeholders (e.g., representatives of the student body, the budget team, and the local community).

This policy statement includes a timescale for measurable goals and commits a member of the senior leadership team to lead on auditing. It also commits the school to working towards building a climate emergency-related brief into all leadership roles in management, subjects, community, business decisions, and building stock, so the policy remains at the heart of priorities and decision-making at [INSERT name of school].

\section{Policy statement}

\section{[INSERT name of school]}

- Acknowledges the rigour and seriousness of the scientific data (e.g., IPCC reports on global warming and UN reports on loss of biodiversity and the consequences of economic growth associated with the climate crisis).

- Accepts the urgency of addressing climate breakdown in civil society, including in schools and their communities.

- Recognises that our purpose as educators, of building bright futures for our children, is severely threatened, unless the climate emergency is tackled.

In declaring a climate emergency at [INSERT name of school], we will:

a Create a Citizen's Assembly from all sectors of the school and its community to generate ideas and create broad-based momentum for acting on the declaration.

b Call on local, state, and/or national government, and/or regulatory or accreditation bodies to provide the necessary policy changes and funding available.

c Mobilise more resources for action-oriented climate change education and skills creation in the school (e.g. by changing budget priorities, working with local and indigenous knowledge holders).

d Commit to being carbon neutral by 2030 and carbon safe by 2050 at the very latest (e.g., by replacing fossil fuels and being accountable for this to the local community).

e Increase the delivery of environmental and sustainability education across curriculum, campus, and community outreach programs (e.g., by undertaking a curriculum audit to ensure its alignment with the declaration, 
operating with an ethical procurement framework to ensure suppliers reduce their carbon footprint, and building partnerships with community groups and stakeholders also on this journey).

At [INSERT name of school], we will:

1 Set up a climate emergency committee reporting to the governing body by [INSERT date].

2 Task the climate emergency committee with revisiting our core vision and values to ensure the wellbeing of people and planet are at the heart of what the school is seeking to achieve by [INSERT date].

3 Require the climate emergency committee to audit our commitments in energy, physical resources and waste streams, transport, biodiversity, food and packaging, sustainable living, and protecting wildlife and the living planet by [INSERT date].

4 Ensure our curriculum, extracurricular activities, and student support foster the skills, knowledge, and attitudes to help create resilient individuals and communities and a more environmentally sustainable world by [INSERT date].

5 Align our policies to prioritise working towards a zero-carbon future by [INSERT date].

6 Inspire change in our community and the wider world to create resilient, hopeful communities in the face of the climate emergency by [INSERT date].

\section{Authorship}

Associate Professor Alan Reid, Monash University

[INSERT RELEVANT STAFF MEMBERS]

\section{Related policy and documents}

[INSERT RELEVANT POLICY AND DOCUMENTS]

\section{Date of ratification}

This policy was ratified on the [INSERT DATE].

\section{Date of review}

This policy will be reviewed by [INSERT DATE]. 


\section{Rating of evidence base}

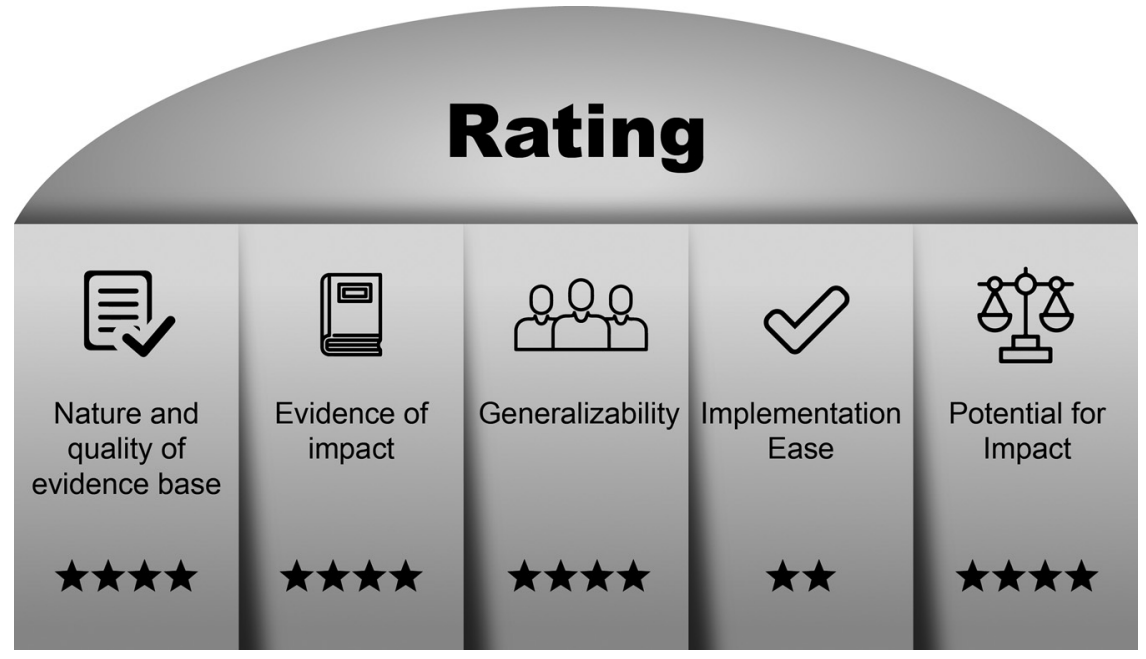

Figure 33.1. Declaring a Climate Emergency Rating of Evidence.

Author Note. The key body of evidence for the topic is the consensus established by the experts at the IPCC (2018), reviewing international data on the climate emergency (Ogunbode et al., 2020; UNFCCC, 1992; 2015). Ignoring the evidence for the climate emergency and the international consensus is untenable in the school sector; doing so can contribute to eco-anxiety (American Psychological Association Task Force on the Interface Between Psychology and Global Climate Change, 2009a; 2009b; Feinstein \& Mach, 2020). The climate emergency affects everyone and can be addressed by all schools (Anderson, 2010; European Parliament, 2019). Preparing to vote on the initial declaration should be relatively easy to achieve. Follow-up on the declaration typically requires systemic changes, relying on strategic action, and additional resources and funds to embed the declaration in the common practices of a school (CRED, 2009; CEE, UNFCCC \& UNESCO, 2017). At a school level, this policy route is a concrete way of signalling commitment to taking action about the climate emergency. It can and should trigger profound changes to curriculum, campus, and community (Anderson, 2010; Monroe et al., 2019; Reid, 2019).

\section{Further reading}

Armstrong, A., Krasny, M., \& Schuldt, J. (2018). Communicating climate change: A guide for educators. Ithaca: Cornell University Press. https:// www.jstor.org/stable/10.7591/j.ctv941wjn

Biesta, G. (2014). The beautiful risk of education. Abingdon: Routledge.

Foster, J. (2015). After sustainability: Denial, hope, retrieval. Abingdon: Routledge.

Maslin, M. (2014). Climate change: A very short introduction. 3rd edition. Oxford: Oxford University Press.

Thunberg, G. (2019). No one is too small to make a difference. London: Penguin Books Ltd. 


\section{Reid}

United Nations Educational, Scientific and Cultural Organization [UNESCO] \& United Nations Framework Committee on Climate Change [UNFCCC]. (2016). Action for Climate Empowerment: Guidelines for accelerating solutions through education, training and public awareness. Paris: UNESCO and UNFCCC. https://unfccc.int/sites/default/files/action_ for_climate_empowerment_guidelines.pdf

\section{Recommended reading}

The following organisations and resources provide examples of policy, templates, and documents to support you in declaring a climate emergency:

B Lab UK. (2020). How to declare a climate emergency \& take climate action: A playbook for business. London: B Lab UK. https://pardot.bcorporation. net/1/39792/2RUI3Wr/99qrgv

Climate Change Teacher Academy. (2020). It starts with you: Better climate education = more climate action. eduCCAteGlobal. https://www.educcateglobal.org

Climate Emergency Declaration and Mobilisation. (2020). Call to declare a climate emergency. Climate Emergency Declaration. https://climateemergency declaration.org/

Council Action in the Climate Emergency. (2020). Council and community action in the climate emergency. CACE. https://www.caceonline.org

Darebin Council. (2018). Darebin climate emergency plan: Darebin climate emergency plan 2017-2022 summary. City of Darebin. http://www.darebin.vic.gov. au/-/media/cityofdarebin/Files/Darebin-Living/CaringfortheEnvironment/Energ yandClimate/ClimateChange/DarebinClimateEmergencyPlanSummary-Dec-2 018.ashx?la=en

Declare a Climate Emergency. (2019). Campaign guide for a climate emergency declaration. Declare a Climate Emergency. https:/www.climateem ergency.uk/blog/campaign-guide-for-a-climate-emergency-declaration/

Extinction Rebellion. (2020). XR educators. Learning Rebellion. https://lea rningrebellion.earth

Global Action Plan. (2019). Climate chaos response toolkit. Global Action Plan. https://www.globalactionplan.org.uk/news/climate-chaos-responsetoolkit-for-schools-is- launched

National Education Union. (2019). How to declare a climate emergency at your school or college. National Education Union. https://neu.org.uk/sites/default/ files/2019-12/Declare $\% 20 \mathrm{a} \% 20$ Climate $\% 20$ Emergency $\% 20 \mathrm{At} \% 20$ Your $\% 20 \mathrm{Sc}$ hool.pdf

Sutton, P. (2017). Local-first implementation: Why a strong climate declaration is needed - At the local government level - And what it can do. RSTI. http://www. green-innovations.asn.au/RSTI/Local=first-implementation_local-govt.pdf

The SDG Accord. (2020). Global universities and colleges climate letter. The SDG Accord. https:/www.sdgaccord.org/climateletter

Teach the Future. (2020). Climate emergency education act. Teach the Future. https://www.teachthefuture.uk 


\section{Expert consultation}

Depending on your circumstances, you may need to consult with key personnel from the following in developing and enacting the policy: your school's leadership team, site staff, student council, local council, education authorities, department/ministry, governing body, funder, network, union, bursar, local environmental bodies, etc.

\section{References}

American Psychological Association Task Force on the Interface Between Psychology and Global Climate Change. (2009a). Psychology and global climate change: Addressing a multi-faceted phenomenon and set of challenges. Report. https://www. apa.org/images/climate-change-booklet_tcm7-91270.pdf

American Psychological Association Task Force on the Interface Between Psychology and Global Climate Change. (2009b). Policy recommendations. https://www.apa.org/ science/about/publications/policy-recommendations.pdf

Anderson, A. (2010). Combating climate change through quality education. Policy brief. Washington, DC: The Brookings Institution. https://www.brookings.edu/wpcontent/uploads/2016/06/09_climate_education.pdf

Armstrong, A., Krasny, M., \& Schuldt, J. (2018). Communicating climate change: A guide for educators. Ithaca: Cornell University Press. https://www.jstor.org/stable/10.7591/j. ctv941wjn

Center for Research on Environmental Decisions [CRED]. (2009). The psychology of climate change communication: A guide for scientists, journalists, educators, political aides, and the interested public. New York: Columbia University. http://guide.cred. columbia.edu/pdfs/CREDguide_full-res.pdf

Centre for Environment Education [CEE], United Nations Framework Convention on Climate Change [UNFCCC], \& United Nations Educational, Scientific and Cultural Organization [UNESCO]. (2017). Good practice in action for climate empowerment: $A$ compilation and analysis of case studies. http://www.ceeindia.org/cee/Good-Practice-i n-Action-for-Climate-Empowerment-A-compilation-and-analysis-of-case-studies.htm

Dillon, J. (2019). University declarations of environment and climate change emergencies. Environmental Education Research, 25(5), 613-614.

Drews, S., \& van den Bergh, J. (2016). What explains public support for climate policies? A review of empirical and experimental studies. Climate Policy, 16(7), 855-876.

Drummond, A., Hall, L., Sauer, C., \& Palmer, J. (2018). Is public awareness and perceived threat of climate change associated with governmental mitigation targets? Climatic Change, 149(2), 159-171.

European Parliament. (2019, November 29). The European Parliament declares climate emergency. https://www.europarl.europa.eu/news/en/press-room/20191121IPR67110/ the-european-parliament-declares-climate-emergency

Feinstein, N., \& Mach, K. (2020). Three roles for education in climate change adaptation. Climate Policy 20(3), 317-322.

Gifford, R. (2011). The dragons of inaction: Psychological barriers that limit climate change mitigation and adaptation. The American Psychologist, 66(4), 290-302.

Hamilton, C., \& Kasser, T. (2009). Psychological adaptation to the threats and stresses of a four degree world. https://www.eci.ox.ac.uk/events/4degrees/ppt/poster-hamilton.pdf

Hestres, L. (2018). Take action now: Motivational framing and action requests in climate advocacy. Environmental Communication, 12(4), 462-479. 


\section{Reid}

Intergovernmental Panel on Climate Change [IPCC]. (2018). Special report on climate change (summary for policymakers). Geneva: IPCC. http://report.ipcc.ch/sr15/pdf/ sr15_spm_final.pdf

Kagawa, F., \& Selby, D. (Eds.) (2010). Education and climate change: Living and learning in interesting times. Abingdon: Routledge.

Ma, Y., Dixon, G., \& Hmielowski, J. (2019). Psychological reactance from reading basic facts on climate change: the role of prior views and political identification. Environmental Communication, 13(1), 71-86.

Monroe, M., Plate, R., Oxarart, A., Bowers, A., \& Chaves, W. (2019). Identifying effective climate change education strategies: A systematic review of the research. Environmental Education Research, 25(6), 791-812.

National Research Council [NRC]. (2010). Informing an effective response to climate change (1st ed.). Washington, DC: National Academies Press.

Ogunbode, C. A., Doran, R., \& Böhm, G. (2020). Exposure to the IPCC special report on $1.5^{\circ} \mathrm{C}$ global warming is linked to perceived threat and increased concern about climate change. Climatic Change, 158, 361-375.

Otto, I. M., Donges, J. F., Cremades, R., Bhowmik, A., Hewitt, R. J., Lucht, W., ... Schellnhuber, H. J. (2020). Social tipping dynamics for stabilizing Earth's climate by 2050. Proceedings of the National Academy of Sciences, 117(5), 2354.

Reid, A. (2019). Climate change education and research: possibilities and potentials versus problems and perils? Environmental Education Research, 25(6), 767-790.

Thunberg, G. (2019). No one is too small to make a difference. London: Penguin Books Ltd.

United Nations Educational, Scientific and Cultural Organization [UNESCO]. (2015). Not just hot air: Putting climate change education into practice. Paris: UNESCO. https://unesdoc.unesco.org/ark:/48223/pf0000233083

United Nations Educational, Scientific and Cultural Organization [UNESCO]. (2019). Country progress on climate change education, training and public awareness: An analysis of country submissions under the United Nations framework convention on climate change. Paris: UNESCO. https://unesdoc.unesco.org/ark:/48223/pf0000372164

United Nations [UN]. (2020). Sustainable development goal 13: Take urgent action to combat climate change and its impacts. https://sustainabledevelopment.un.org/sdg13

United Nations Educational, Scientific and Cultural Organization [UNESCO] \& United Nations Framework Convention on Climate Change [UNFCCC]. (2016). Action for climate empowerment: Guidelines for accelerating solutions through education, training and public awareness. Paris: UNESCO and UNFCCC. https:// unfccc.int/sites/default/files/action_for_climate_empowerment_guidelines.pdf

United Nations Educational, Scientific and Cultural Organization [UNESCO]. (2016). Global education monitoring report: Education for people and planet: Creating sustainable futures for all. Paris: UNESCO. http://gem-report-2016.unesco.org/en/home/

United Nations Framework Convention on Climate Change [UNFCCC]. (1992). United Nations framework convention on climate change. Paris: United Nations. http s://unfccc.int/resource/docs/convkp/conveng.pdf

United Nations Framework Convention on Climate Change [UNFCCC]. (2015). Adoption of the Paris agreement. 21st conference of the parties. Paris: United Nations.

UNICEF. (2012). Climate change adaptation and disaster risk reduction in the education sector. New York: UNICEF Division of Communication. https://www.unicef. org/cfs/files/UNICEF-ClimateChange-ResourceManual-lores-c.pdf

Whitmarsh, L., O'Neill, S., \& Lorenzoni, I. (Eds.) (2010). Engaging the public with climate change: Behaviour change and communication. London: Earthscan.

Wibeck, V. (2014). Enhancing learning, communication and public engagement about climate change: Some lessons from recent literature. Environmental Education Research, 20(3), 387-411. 